EXTENDED REPORT

\title{
Dosage dependency of intravitreal triamcinolone acetonide as treatment for diabetic macular oedema
}

\author{
U H M Spandau, M Derse, P Schmitz-Valckenberg, C Papoulis, J B Jonas
}

Br J Ophthalmol 2005;89:999-1003. doi: 10.1136/bjo.2004.062596

See end of article for authors' affiliations

.....................

Correspondence to: Dr U Spandau, Universitäts-Augenklinik, Theodor-Kutzer-Ufer 1-3, 68167 Mannheim, Germany; ulrich.spandau@augen. ma.uni-heidelberg.de

Accepted for publication 1 January 2005

\begin{abstract}
Aim: To evaluate the effect of different doses of intravitreal triamcinolone acetonide on diffuse diabetic macular oedema.

Methods: The prospective, randomised, double masked, clinical interventional study included 27 eyes (27 patients) with diffuse diabetic macular oedema. They were randomly divided into three study groups receiving an intravitreal injection of filtered triamcinolone acetonide of about $2 \mathrm{mg}$ ( $\mathrm{n}=8$ eyes), $5 \mathrm{mg}$ $(n=10)$, or $13 \mathrm{mg}(\mathrm{n}=9)$, respectively. Dosage measurement was performed before filtration. Mean follow up was 6.6 (SD 2.4) months (3-12 months). Main outcome measures were visual acuity and intraocular pressure.

Results: Maximal increase in visual acuity was significantly $(\mathrm{p}=0.046 ; 95 \% \mathrm{Cl}: 0.032$ to $2.99 ; r=0.38$ ) correlated with the dosage of intravitreal triamcinolone acetonide. Additionally, the duration of the effect of intravitreal triamcinolone acetonide increased significantly with the dosage of intravitreal triamcinolone acetonide $(r=0.45 ; p=0.014)$. Increase in intraocular pressure during follow up was statistically not significantly associated with the dosage used $(p=0.77)$.

Conclusions: In patients with diffuse diabetic macular oedema receiving intravitreal triamcinolone acetonide, treatment response may last longer and be more pronounced with a dosage of $13 \mathrm{mg}$ than in lower doses of $5 \mathrm{mg}$ or $2 \mathrm{mg}$. Triamcinolone acetonide induced increase in intraocular pressure may not be markedly associated with the dosage used.
\end{abstract}

M acular oedema is one of the most important reasons for reduced vision in patients with diabetic retinopathy. If there is focal leakage of fluid in the macular region, in contrast with a diffuse leakage, it can be treated by focal argon laser coagulation of the leaking retinal area. ${ }^{12}$ If capillary leakage and macular oedema diffusely involve the posterior pole of the fundus, the therapeutic value of scattered laser coagulation of the macula has not yet conclusively been shown. ${ }^{3}{ }^{4}$ Recent studies have suggested that intravitreal triamcinolone acetonide may be an alternative treatment option leading to a reduction of macular oedema, and depending on the degree of macular ischaemia, to an increase in visual acuity. ${ }^{5-16}$

In these studies, however, different doses varying between about $4 \mathrm{mg}$ to about $20 \mathrm{mg}$ triamcinolone acetonide have been employed..$^{5-16}$ It is unknown so far whether efficacy and duration of the effect of intravitreal triamcinolone acetonide are dosage dependent. The purpose of the present study was, therefore, to investigate a dosage dependency concerning duration and efficacy of intravitreal triamcinolone acetonide in the treatment of diffuse diabetic macular oedema.

\section{PATIENTS AND METHODS}

The clinical interventional randomised prospective study included 27 eyes (27 patients) with diabetic macular oedema according to the ETDRS definition. ${ }^{17}$ The assessment of diabetic macular oedema was based on the ophthalmoscopic examination, fluorescein angiography and optical coherent tomography of the macula. Mean age of the patients was 69.7 (SD 9.6) years (median 70 years; range $48-84$ years). Visual acuity at baseline of the study was 0.17 (0.18) (median 0.125; $\log$ MAR units $1.00(0.51)$ ). Minimal follow up was 3 months. All patients were fully informed about the experimental character of the treatment and consent was obtained from the patients after the nature of the procedure was explained. The ethics committee of the university had approved the study, which followed the tenets of the Declaration of Helsinki.

Eight eyes $(30 \%)$ were treated with $4 \mathrm{mg}$ triamcinolone acetonide, $10(37 \%)$ eyes received $8 \mathrm{mg}$ triamcinolone acetonide intravitreally, and nine $(33 \%)$ eyes were treated with $25 \mathrm{mg}$ intravitreal triamcinolone acetonide. During follow up, no other ocular treatment of diabetic retinopathy or any ocular surgery was performed. All eyes included into the study had received their last retinal laser treatment at least 3 months before inclusion into the study. If the criteria for retinal laser treatment according to the ETDRS study were not fulfilled, laser treatment had not been performed. ${ }^{12}$ In none of the eyes, had any intravitreal injection been performed before inclusion into the study. The randomisation of the patients into the study groups was performed in a masked manner by the hospital pharmacy. All three study groups did not vary significantly in baseline visual acuity and frequency of pseudophakia $(p>0.60)$ (table 1). Surgeon and examiner during follow up were masked for the dosage injected. All patients received a single intravitreal injection of triamcinolone acetonide in $0.4 \mathrm{ml}$ Ringer's solution as described previously. ${ }^{5}$

The hospital pharmacy prepared the triamcinolone acetonide for intraocular injection by removing the solvent agent, benzyl alcohol, and replacing it with Ringer's solution as previously described in detail. ${ }^{568}$ Briefly, the triamcinolone acetonide was prepared by extracting $0.1 \mathrm{ml}$ (for an intended dosage of $4 \mathrm{mg}$ ), $0.2 \mathrm{ml}$ (for an intended dosage of $8 \mathrm{mg}$ ), and $0.625 \mathrm{ml}$ (for an intended dosage of $25 \mathrm{mg}$ ) from the ampoule (Volon A, Bristol-Myers-Squibb, Germany) containing $40 \mathrm{mg}$ of triamcinolone acetonide in $1 \mathrm{ml}$. The extracted volume was put into a tuberculin syringe $(1 \mathrm{ml})$. The syringe was filled up with Ringer's solution. A millipore filter (pore size, $5 \mu \mathrm{m}$; Sterifix Pury, B Braun Melsungen AG, CarlBraun-Strasse 1, 34212 Melsungen, Germany) was placed on top of the syringe, and most of the content of the syringe 


\begin{tabular}{|c|c|c|c|c|}
\hline & $2 \mathrm{mg}$ & $5 \mathrm{mg}$ & $13 \mathrm{mg}$ & $\mathrm{p}$ Value \\
\hline Number & 8 & 10 & 9 & \\
\hline Age & $67.9(13.2)$ & $69.7(9.7)$ & $71.1(6.9)$ & 0.53 (NS) \\
\hline Follow up (months) & $6.8(2.1)$ & $6.3(2.6)$ & $6.7(2.5)$ & 0.70 (NS) \\
\hline Visual acuity at baseline & $0.18(0.16)$ & $0.18(0.23)$ & $0.15(0.13)$ & 0.66 (NS) \\
\hline $\begin{array}{l}\text { Intraocular pressure at } \\
\text { baseline }(\mathrm{mm} \mathrm{Hg})\end{array}$ & $14.1(1.4)$ & $14.4(1.4)$ & $14.9(1.2)$ & 0.23 (NS) \\
\hline
\end{tabular}

(about $0.8 \mathrm{ml}$ ) was pressed through the filter, with the triamcinolone acetonide crystals remaining in the syringe. The syringe was refilled with Ringer's solution, and the same procedure was repeated three times. A volume of $0.4 \mathrm{ml}$ containing the triamcinolone acetonide crystals was injected intravitreally. The filtration procedure had been routinely performed by the staff of the hospital pharmacy for more than 1 year.

Since the concentration of triamcinolone acetonide decreases by the filtration, ${ }^{18} 15$ filtered probes with $4 \mathrm{mg}$ $(\mathrm{n}=5), 8 \mathrm{mg}(\mathrm{n}=5)$, and $25 \mathrm{mg}(\mathrm{n}=5)$ triamcinolone acetonide were additionally prepared to measure the final triamcinolone acetonide concentration prior to injection. High phase liquid chromatography assay with a sensitivity of $0.1 \mathrm{mg} / \mathrm{l}$ was employed to measure the triamcinolone acetonide concentrations.

At baseline of the study, visual acuity was determined and fluorescein angiography was performed. After inclusion into the study, the patients were re-examined the first day after the injection, l week, 1 month after the injection, and from then on at 3 month intervals. Mean follow up was 6.6 (2.4) months (range 3-12 months). Visual acuity was determined in a standardised fashion by an observer performing best corrected refractometry and using ETDRS charts. ${ }^{2}$ The examiner measuring visual acuity was masked. He knew that the examined patient had received an intravitreal injection of triamcinolone acetonide but the dosage was not known to him. Visual acuity measurements were converted to the logarithm of the minimum angle of resolution $(\log M A R)$.

Statistical analyses were performed by using a commercially available statistical software package (SPSS for Windows, version 11.5, SPSS, Chicago, IL, USA). The level of significance was 0.05 (two sided) in all statistical testing.

\section{RESULTS}

In the 15 filtered probes examined to determine the final dosage of triamcinolone acetonide ready for injection, measurements showed a final pre-injection dosage of 2.4 (0.8) $\mathrm{mg}$ triamcinolone acetonide in the group of probes with an original dosage of $4 \mathrm{mg}$ triamcinolone acetonide before the filtration process; of $5.2(0.6) \mathrm{mg}$ triamcinolone acetonide in the group of probes with an original dosage of $8 \mathrm{mg}$ triamcinolone acetonide before the filtration process; and of $12.8(0.7) \mathrm{mg}$ triamcinolone acetonide in the group of probes with an original dosage of $25 \mathrm{mg}$ triamcinolone acetonide before the filtration process. ${ }^{19}$ The three study groups in the present investigation were, therefore, termed the " $2 \mathrm{mg}$ study group," the "5 mg study group," and the "13 mg study group." ${ }^{\prime 2}$

In the $2 \mathrm{mg}$ study group, visual acuity increased slightly, however, not statistically significantly $(p=0.13)$, from 0.18 (0.16) at baseline to a peak of $0.2(0.21)$ after 1 month follow up (table 2). From this peak visual acuity, it decreased to a value of $0.19(0.16)$ towards the end of the follow up (table 2 ). Visual acuity measurements obtained at the end of follow up and baseline visual acuity did not differ significantly $(\mathrm{p}=0.57)$ (table 2$)$. Visual acuity at baseline $(0.18(0.16))$ and maximal visual acuity during follow up $(0.23(0.20))$ did not vary significantly $(\mathrm{p}=0.09 ; 95 \% \mathrm{CI}$ : -0.010 to 0.108$)$. The duration of the effect of intravitreal triamcinolone acetonide defined as the time, when visual acuity started to decline again, was at 0.92 (1.25) months after the injection.

In the $5 \mathrm{mg}$ study group, visual acuity increased, however not statistically significantly $(p=0.15 ; 95 \% \mathrm{CI}$ : -0.025 to $0.120)$, from $0.18(0.23)$ at baseline to a peak of $0.30(0.28)$ at 6 months after the injection (table 2). From this peak in visual acuity, it decreased to a value of $0.11(0.10)$ at 9 months after the injection. Visual acuity measurements obtained at the end of follow up were not significantly better than baseline visual acuity ( $\mathrm{p}=0.076 ; 95 \% \mathrm{CI}:-0.004$ to 0.066) (table 2). Maximal visual acuity during follow up $(0.23(0.23))$ was significantly $(\mathrm{p}=0.012 ; 95 \% \mathrm{CI}: 0.014$ to $0.0884)$ higher than visual acuity at baseline $(0.18(0.23))$. The duration of the effect of intravitreal triamcinolone acetonide was 2.30 (2.63) months.

In the $13 \mathrm{mg}$ study group, visual acuity increased statistically significant from $0.15(0.13)$ at baseline to a plateau ranging between $0.23(0.13)(\mathrm{p}=0.014)$ at 1 week after the injection, $0.26(0.18)(\mathrm{p}=0.019)$ at 3 months after the injection and $0.25(0.12)(\mathrm{p}=0.030)$ at 6 months after the injection (table 2). At the end of follow up, visual acuity was $0.24(0.13)$. Visual acuity measurements obtained at the end of follow up were significantly better than baseline visual acuity ( $p=0.023$ ) (table 2 ). Correspondingly, maximal visual acuity during follow up $(0.30(0.18))$ was significantly $(\mathrm{p}=0.002 ; 95 \%$ CI: 0.071 to 0.232$)$ higher than visual acuity at baseline $(0.15(0.13))$. The duration of the effect of intravitreal triamcinolone acetonide was 4.33 (3.91) months.

Comparing the three study groups with each other showed that the maximal gain in visual acuity was significantly $(\mathrm{p}=0.031,95 \% \mathrm{CI}:-0.194$ to -0.011$)$ larger in the with $13 \mathrm{mg}$ triamcinolone acetonide group compared to the $2 \mathrm{mg}$ triamcinolone acetonide group. Correspondingly, the maximal increase in visual acuity, determined in Snellen lines, was significantly ( $p=0.046$; $95 \%$ CI: 0.032 to 2.99 ; correlation coefficient $r=0.38$ ) correlated with the dosage of intravitreal triamcinolone acetonide (fig 1 ). The duration of the effect of intravitreal triamcinolone acetonide was significantly $(p=0.031)$ longer in the $13 \mathrm{mg}$ intravitreal triamcinolone acetonide group than in the $2 \mathrm{mg}$ intravitreal triamcinolone acetonide group (table 2). Duration of the effect of intravitreal triamcinolone acetonide increased significantly with increasing dosage of intravitreal triamcinolone acetonide (correlation coefficient $r=0.45 ; \mathrm{p}=0.014$ ) (fig 2). The number of eyes showing an increase in best visual acuity by two or more Snellen lines during the follow up was higher; however not significantly $(\mathrm{p}=0.12)$, in the $13 \mathrm{mg}$ study group (7/9) than in the $5 \mathrm{mg}(6 / 11)$ and $2 \mathrm{mg}$ study groups (3/8).

Intraocular pressure did not vary significantly between all three study groups at baseline of the study (tables 1, 3). In all 
Table 2 Measurement of visual acuity (ETDRS lines) (median (SD)) and gain in visual acuity (Snellen lines) after intravitreal injection of $4 \mathrm{mg}, 8 \mathrm{mg}$, or $25 \mathrm{mg}$ triamcinolone acetonide

\begin{tabular}{|c|c|c|c|c|c|}
\hline Time & No & Visual acuity & LogMAR units & $p$ Value & $\begin{array}{l}\text { Gain in visual acuity (Snellen } \\
\text { lines) }\end{array}$ \\
\hline \multicolumn{6}{|l|}{$2 \mathrm{mg}$ study group } \\
\hline Pre-injection & 8 & $0.18(0.16)$ & $0.91(0.39)$ & & \\
\hline 1 week & 6 & $0.19(0.17)$ & $0.89(0.44)$ & 0.92 (NS) & $0.50(2.37)$ \\
\hline 1 month & 7 & $0.23(0.21)$ & $0.83(0.49)$ & 0.22 (NS) & $0.64(2.93)$ \\
\hline 3 months & 8 & $0.22(0.21)$ & $0.80(0.39)$ & 0.20 (NS) & $0.39(2.26)$ \\
\hline 6 months & 6 & $0.21(0.22)$ & $0.86(0.44)$ & 0.58 (NS) & $0.42(2.06)$ \\
\hline 9 months & 3 & $0.23(0.23)$ & $0.77(0.40)$ & 0.20 (NS) & $0.83(0.76)$ \\
\hline Max during follow up & 8 & $0.23(0.19)$ & $0.80(0.39)$ & 0.09 (NS) & $1.13(2.42)$ \\
\hline At end of follow up & 8 & $0.19(0.16)$ & $0.85(0.38)$ & 0.57 (NS) & $0.63(2.00)$ \\
\hline Maximal gain & 8 & $0.05(0.07)$ & $-0.10(0.10)$ & $1.13(2.42)$ & \\
\hline Duration of effect (months) & 8 & $0.92(1.25)$ & & & \\
\hline Gain $\geqslant 2$ Snellen lines & $3 / 8(38 \%)$ & & & & \\
\hline \multicolumn{6}{|l|}{$5 \mathrm{mg}$ study group } \\
\hline Pre injection & 10 & $0.18(0.23)$ & $1.00(0.53)$ & & \\
\hline 1 week & 4 & $0.08(0.04)$ & $1.14(0.26)$ & 0.48 (NS) & $-0.50(5.68)$ \\
\hline 1 month & 8 & $0.24(0.25)$ & $0.79(0.43)$ & 0.21 (NS) & $0.88(1.36)$ \\
\hline 3 months & 8 & $0.13(0.09)$ & $0.99(0.37)$ & 0.34 (NS) & $1.13(1.81)$ \\
\hline 6 months & 6 & $0.30(0.28)$ & $0.72(0.46)$ & 0.15 (NS) & $1.33(2.25)$ \\
\hline 9 months & 4 & $0.11(0.10)$ & $1.11(0.40)$ & 0.12 (NS) & $2.50(2.08)$ \\
\hline Max during follow up & 10 & $0.23(0.23)$ & $0.82(0.41)$ & 0.012 & $1.90(1.73)$ \\
\hline At end of follow up & 10 & $0.21(0.23)$ & $0.86(0.42)$ & 0.076 (NS) & $1.20(1.99)$ \\
\hline Maximal gain & 10 & $0.05(0.05)$ & $-0.18(0.23)$ & $2.09(1.76)$ & \\
\hline Duration of effect (months) & & $2.30(2.63)$ & & & \\
\hline Gain $\geqslant 2$ lines & $5 / 10(50 \%)$ & & & & \\
\hline \multicolumn{6}{|l|}{$13 \mathrm{mg}$ study group } \\
\hline Pre injection & 9 & $0.15(0.13)$ & $1.11(0.61)$ & & \\
\hline 1 week & 6 & $0.23(0.13)$ & $0.71(0.30)$ & 0.014 & $4.80(4.49)$ \\
\hline 1 month & 8 & $0.22(0.16)$ & $0.79(0.39)$ & 0.011 & $3.50(4.14)$ \\
\hline 3 months & 9 & $0.26(0.18)$ & $0.71(0.39)$ & 0.019 & $3.63(4.75)$ \\
\hline 6 months & 8 & $0.26(0.12)$ & $0.65(0.27)$ & 0.030 & $3.63(4.44)$ \\
\hline 9 onths & 2 & $0.25(0.21)$ & $0.70(0.43)$ & 0.037 & $4.50(4.95)$ \\
\hline Max during follow up & 9 & $0.30(0.18)$ & $0.66(0.40)$ & 0.002 & $4.11(4.37)$ \\
\hline At end of follow up & 9 & $0.24(0.13)$ & $0.71(0.36)$ & 0.023 & $3.56(4.75)$ \\
\hline Maximal gain & 9 & $0.15(0.10)$ & $-0.46(0.53)$ & $4.11(4.37)$ & \\
\hline Duration of effect 9 (months) & $4.33(3.91)$ & & & & \\
\hline Gain $\geqslant 2$ lines & $7 / 9(78 \%)$ & & & & \\
\hline
\end{tabular}

The dosage was measured before filtration of the triamcinolone acetonide crystals. Peak time was defined as the time, at which visual acuity started to decline again. $\mathrm{p}$ Value, difference to the baseline value in each study group; NS, statistically not significant.

three study groups, intraocular pressure increased during follow up. For the $5 \mathrm{mg}$ study group, the difference between the baseline intraocular pressure value and the highest value during follow up was statistically significant $(\mathrm{p}=0.005)$. For the two other groups, the differences were not statistically significant $(p=0.15)$. Correspondingly, the increase in intraocular pressure during follow up was statistically not significantly associated with the dosage used $(\mathrm{p}=0.77)$.

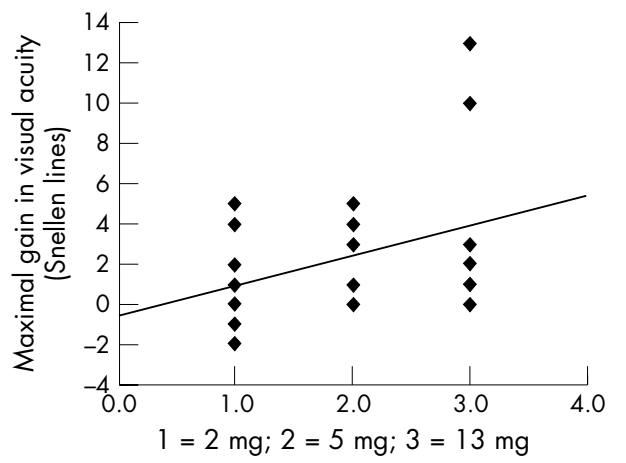

Figure 1 Scatter plot showing the correlation between the dosage of intravitreally injected triamcinolone acetonide and maximal gain in visual acuity during follow up $(\mathrm{p}=0.046 ; 95 \% \mathrm{Cl}$ : 0.032 to 2.99 ; correlation coefficient $r=0.38$; equation of the regression line: (maximal gain in visual acuity) $=1.51+$ (dosage study group number) -0.60 .

\section{DISCUSSION}

Recent studies on diabetic macular oedema have suggested that intravitreal triamcinolone acetonide may be useful to increase visual acuity in patients with diffuse diabetic macular oedema. ${ }^{5-16}$ In case series studies and in a recent randomised study, doses of $4 \mathrm{mg}$ or about $20 \mathrm{mg}$ triamcinolone acetonide were used and resulted in a significant

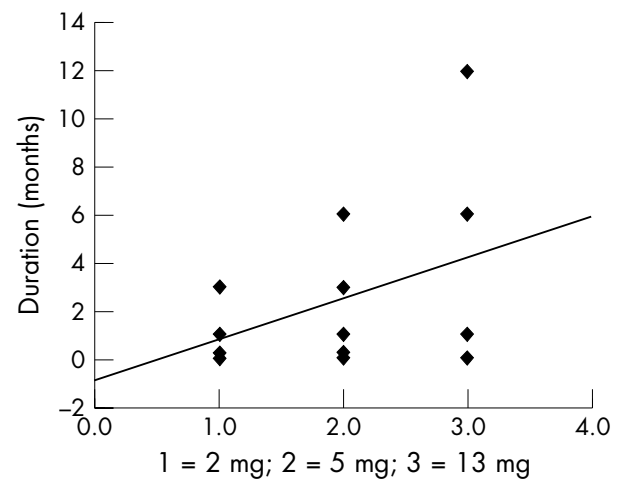

Figure 2 Scatter plot showing the correlation between the dosage of intravitreally injected triamcinolone acetonide and the duration of the effect of intravitreal triamcinolone acetonide $(p=0.014$; correlation coefficient $r=0.45 ; 95 \% \mathrm{Cl}: 0.498$ to 2.977 ; equation of the regression line: (peak time in months) $=1.71+$ (dosage study group number) -0.92 . 


\begin{tabular}{llll}
\hline Table 3 & Change in intraocular pressure (IOP) during follow up & \\
\hline IOP $(\mathbf{m m ~ H g})$ & $\mathbf{2} \mathbf{~ m g ~ g r o u p ~}$ & $\mathbf{5 ~} \mathbf{~ m g ~ g r o u p ~}$ & $\mathbf{1 3} \mathbf{~ m g ~ g r o u p ~}$ \\
\hline Baseline & $14.1(1.4)$ & $14.4(1.4)$ & $14.9(1.2)$ \\
Maximal value & $15.4(1.7)$ & $17.7(2.7)$ & $16.2(2.0)$ \\
Maximal increase & $1.5(2.4)$ & $3.6(2.6)$ & $1.3(2.4)$ \\
At study end & $14.9(1.7)$ & $16.7(1.3)$ & $15.6(2.6)$ \\
\hline
\end{tabular}

increase in visual acuity compared to visual acuity measurements obtained at baseline. ${ }^{6-16}$ Using a dosage of about $20 \mathrm{mg}$ triamcinolone acetonide, the increase in visual acuity was most marked for the first 3-6 months after the injection, and was present during a period of about 6-9 months. ${ }^{20}$ Using a dosage of $4 \mathrm{mg}$, the duration of the effect of intravitreal triamcinolone acetonide as measured by a reduction in macular thickness by optical coherence tomography was less than 6 months. $^{79}$ At the end of follow up, visual acuity measurements often returned to the baseline values with no significant difference between baseline values and the measurements obtained at the end of follow up.

These preceding investigations comparing indirectly the duration of the effect of intravitreal triamcinolone acetonide have been confirmed by the present study. The duration of the effect of intravitreal triamcinolone acetonide increased significantly with increasing dosage (fig 2). Interestingly, the maximal gain in visual acuity after the intravitreal injection was significantly ( $p=0.031$ ) higher in the $13 \mathrm{mg}$ study group than in the $2 \mathrm{mg}$ study group corresponding to a significant correlation between the post-injection increase in visual acuity and the dosage of triamcinolone acetonide (fig l). These data may suggest that the amount of post-injection increase in visual acuity and the duration of the effect of intravitreal triamcinolone acetonide show a dosage dependency. It may have implications for the discussion on the dosage of intravitreal triamcinolone acetonide to be used as treatment for diffuse diabetic macular oedema, and for the discussion on how to reduce the frequency of required intravitreal re-injections.

Regarding side effects, none of the study groups showed an infectious or sterile endophthalmitis, pseudo-endophthalmitis, or a marked progression of cataract as assessed by slit lamp biomicroscopy..$^{21-31}$ The study sample, however, may have been too small to statistically address these questions since most side effects such as infectious endophthalmitis may have a frequency of less than $1 \%$. One may argue that the presumably lower frequency of intravitreal re-injections by using a higher dosage may lead to a lower frequency of injection associated complications such as endophthalmitis. The finding in the present study, that the increase in intraocular pressure may be independent of the dosage used, is in agreement with previous independent investigations, in which the frequency of elevated intraocular pressure after the intravitreal injection of triamcinolone acetonide did not vary between studies using a dosage of $4 \mathrm{mg}$ compared with studies using a dosage of about $20 \mathrm{mg} .{ }^{30} 31$

There are limitations to the present study. One of them is the possible inaccuracy of the final dosage of triamcinolone acetonide after the filtration process before the injection. In the setting of this study, an original dosage of $25 \mathrm{mg}$ triamcinolone acetonide may have been a dosage of about $13 \mathrm{mg}$ to be injected, and an original dosage of $4 \mathrm{mg}$ triamcinolone acetonide may have been a dosage of about $2.5 \mathrm{mg}$ to be injected. It may a be weakness of many studies using filtered triamcinolone acetonide for intravitreal injection. $^{18}{ }^{19}$ It has to be taken into account, however, that the standard deviation of the triamcinolone acetonide doses after the filtration was relatively low, suggesting that the filtration process led to a reproducible reduction of the triamcinolone acetonide dosage. The examinations suggest that the filtration process did not markedly change the ratio between the study groups in the dosage of triamcinolone acetonide (unfiltered dosage $25 \mathrm{mg}$ (filtered: about $13 \mathrm{mg}$ ) to unfiltered $4 \mathrm{mg}$ (filtered: about $2.5 \mathrm{mg}$ ) or about 6:1). The examinations additionally show that for the $13 \mathrm{mg}$ study group (before filtration: $25 \mathrm{mg}$ ), the pre-injection dosage of filtered triamcinolone acetonide was still considerably higher than the dosage of $4 \mathrm{mg}$ unfiltered triamcinolone acetonide as used in other investigations. ${ }^{79}$ Another limiting factor of this study might be the relatively small number of patients included in the study. Despite this, however, the postinjection increase in visual acuity as well as the duration of the effect was significantly larger in the $13 \mathrm{mg}$ study group than in the $2 \mathrm{mg}$ study group. The small number of patients may, therefore, support the conclusions of the study.

In conclusion, the data of this study suggest that, in patients with diffuse diabetic macular oedema, treatment response may last longer and may be more pronounced with a dosage of $13 \mathrm{mg}$ triamcinolone acetonide compared with a dosage of $5 \mathrm{mg}$ or $2 \mathrm{mg}$ triamcinolone acetonide. Triamcinolone acetonide induced increase in intraocular pressure may not markedly be associated with the dosage used.

\section{Authors' affiliations}

U H M Spandau, M Derse, P Schmitz-Valckenberg, C Papoulis, Department of Ophthalmology, Evangelisches Stift, Koblenz, Germany U H M Spandau, J B Jonas, Department of Ophthalmology, Faculty of Clinical Medicine Mannheim, University of Heidelberg, Germany

Competing interests: none declared

\section{REFERENCES}

1 Early Treatment Diabetic Retinopathy Study Research Group. Photocoagulation for diabetic macular edema. ETDRS report number 1. Arch Ophthalmol 1985;103:1796-806.

2 Early Treatment Diabetic Retinopathy Study Research Group. Early photocoagulation for diabetic retinopathy. ETDRS report number 9 . Ophthalmology 1991;98:766-85.

3 McDonald HR, Schatz H. Grid photocoagulation for diffuse macular edema. Retina 1985;5:65-72.

4 Lee CM, Olk RJ. Modified grid laser photocoagulation for diffuse diabetic macular edema. Long-term visual results. Ophthalmology 1991;98:1594-602.

5 Jonas JB, Söfker A. Intraocular injection of crystalline cortisone as adjunctive treatment of diabetic macular edema. Am J Ophthalmol 2001;132:425-7.

6 Jonas JB, Hayler JK, Söfker A, et al. Intravitreal injection of crystalline cortisone as adjunctive treatment of proliferative diabetic retinopathy. Am J Ophthalmol 2001;131:468-71.

7 Martidis A, Duker JS, Greenberg PB, et al. Intravitreal triamcinolone for refractory diabetic macular edema. Ophthalmology 2002;109:920-7.

8 Jonas JB, Kreissig I, Söfker A, et al. Intravitreal injection of triamcinolone acetonide for diabetic macular edema. Arch Ophthalmol 2003;121:57-61.

9 Massin P, Audren F, Haouchine B, et al. Intravitreal triamcinolone acetonide for diabetic diffuse macular edema: preliminary results of a prospective controlled trial. Ophthalmology 2004;111:218-24.

10 Al-Haddad CE, Jurdi FA, Bashshur ZF. Intravitreal triamcinolone acetonide for the management of diabetic papillopathy. Am J Ophthalmol 2004;137:1151-3.

11 Sutter FK, Simpson JM, Gillies MC. Intravitreal triamcinolone for diabetic macular edema that persists after laser treatment Three-month efficacy and safety results of a prospective, randomized, double-masked, placebocontrolled clinical trial. Ophthalmology 2004;111:2044-9. 
12 Negi AK, Vernon SA, Lim CS, et al. Intravitreal triamcinolone improves vision in eyes with chronic diabetic macular oedema refractory to laser photocoagulation. Eye 2004 (Epub ahead of print.)

13 Jonas JB, Akkoyun I, Kreissig I, et al. Diffuse diabetic macular oedema treated by intravitreal triamcinolone acetonide: a prospective comparative nonrandomised study. Br J Ophthalmol 2005;89:321-6.

14 Jonas JB, Harder B, Kamppeter B. Inter-eye difference in diabetic macular edema after unilateral intravitreal injection of triamcinolone acetonide. Am J Ophthalmol 2005 (in press)

15 Jonas JB, Kreissig I, Degenring RF, et al. Repeated intravitreal injection of triamcinolone acetonide for diffuse diabetic macular oedema. Br J Ophthalmol 2005;89:122.

16 Jonas JB, Martus P, Degenring RF, et al. Predictive factors for visual acuity change after intravitreal triamcinolone for diabetic macular edema. Arch Ophthalmol 2005 (in press).

17 Early Treatment Diabetic Retinopathy Study Research Group. Classification of diabetic retinopathy from fluorescein angiograms. ETDRS report number 11. Ophthalmology 1991;98:807-22.

18 Rodriguez-Coleman $\mathrm{H}$, Yuan $\mathrm{P}, \mathrm{Kim} \mathrm{H}$, et al. Intravitreal injection of triamcinolone for diffuse macular edema. Arch Ophthalmol. 2004;122 1085-6; author reply 1086-8).

19 Spandau UHM, Derse M, Schmitz-Valckenberg P, et al. Measurement of triamcinolone acetonide concentration after filtering of solvent agent. Am J Ophthalmol 2005 (in press).

20 Jonas JB, Degenring R, Kamppeter B, et al. Duration of the effect of intravitreal triamcinolone acetonide as treatment of diffuse diabetic macular edema. Am J Ophthalmol 2004;138:158-60.
21 Benz MS, Murray TG, Dubovy SR, et al. Endophthalmitis caused by Mycobacterium chelonae abscessus after intravitreal injection of triamcinolone. Arch Ophthalmol 2003;121:271-3.

22 Jonas JB, Kreissig I, Degenring RF. Endophthalmitis after intravitreal injection of triamcinolone acetonide. Arch Ophthalmol 2003;121:1663-4.

23 Moshfeghi DM, Kaiser PK, Scott IU, et al. Acute endophthalmitis following intravitreal triamcinolone acetonide injection. Am J Ophthalmol 2003; 136:791-6

24 Nelson ML, Tennant MT, Sivalingam A, et al. Infectious and presumed noninfectious endophthalmitis after intravitreal triamcinolone acetonide injection. Retina 2003;23:686-91.

25 Parke DW. Intravitreal triamcinolone and endophthalmitis. Am J Ophthalmol 2003;136:918-19.

26 Roth DB, Chieh J, Spirn MJ, et al. Noninfectious endophthalmitis associated with intravitreal triamcinolone injection. Arch Ophthalmol 2003;121:1279-82

27 Sutter FK, Gillies MC. Pseudo-endophthalmitis after intravitreal injection of triamcinolone. Br J Ophthalmol 2003;87:972-4

28 Gillies MC, Simpson JM, Billson FA, et al. Safety of an intravitreal injection of triamcinolone: results from a randomized clinical trial. Arch Ophthalmol 2004; 122:336-40.

29 Wingate RJ, Beaumont PE. Intravitreal triamcinolone and elevated intraocular pressure. Aust N Z J Ophthalmol 1999;27:431-2.

30 Jonas JB, Kreissig I, Degenring R. Intraocular pressure after intravitrea injection of triamcinolone acetonide. Br J Ophthalmol 2003;87:24-7.

31 Smithen LM, Ober MD, Maranan L, et al. Intravitreal triamcinolone acetonide and intraocular pressure. Am J Ophthalmol 2004;138:740-3. 